\title{
INVESTIGAÇÃO DO USO DA TAPELA PERIÓDICA NA PERCEPÇÃO DOS DISCENTES DO ENSINO MÉDIO DO MUNICÍPIO DE CAJAZEIRAS-PB
}

\begin{abstract}
Luislândia Vieira de Figueiredo*; (Graduanda em Química na Universidade Federal de Campina GrandeUFCG)

EgleKatarinne Souza da Silva; (Graduanda em Química na Universidade Federal de Campina Grande-UFCG)

Maricélia Lucena Ferreira; (Graduanda em Química na Universidade Federal de Campina Grande-UFCG) Luciano Leal de Morais Sales; (Prof. Adjunto iv da Unidade Acadêmica de Ciências Exatas e da Natureza do Centro de Formação de Professores da Universidade Federal de Campina Grande-UFCG)

*E-mail:Luislandia fiqueredo@hotmail.com
\end{abstract}

resumo:

A presente pesquisa foi desenvolvida com o intuito de obter as principais percepções dos discentes do $1^{\circ}$ ano do Ensino Médio, na Escola Técnica de Saúde do Centro de Formação de Professores da UFCG, Cajazeiras- PB, a respeito da importância do estudo da tabela periódica, assim como investigar se os alunos sabem utilizar a tabela de forma correta nas aulas de Química. O instrumento de pesquisa constituiu-se de um questionário aplicado com 30 alunos. Após a coleta de dados os resultados obtidos foram analisados, quantificados e transformados em gráficos. Verificou-se que, cerca de $60 \%$ dos entrevistados gostam de estudar Química por ser uma matéria relacionada ao cotidiano. Observou-se ainda que $45 \%$ dos alunos responderam ser importante o uso da tabela periódica, pois ajuda na compreensão dos conteúdos químicos. Por último, verificou-se que cerca de $77 \%$ dos discentes reconheceram não saber utilizar a tabela periódica de forma correta, isso deve-se a grande complexidade do assunto. A partir destes dados ficou evidente a importância do estudo da tabela periódica na disciplina de Química. Fica clara a deficiência dos discentes em relação à utilização correta da tabela, portanto, torna-se necessário que os docentes utilizem novas metodologias de ensino na abordagem deste tema, visando promover uma aprendizagem significativa.

\section{palavras-chave:}

Ensino de Química; Tabela Periódica; Aprendizagem Significativa. 



\section{I NTRODUÇÃO}

Segundo autores da educação, o ensino de Química sempre foi alvo de grandes dificuldades. Um exemplo disso, é o Estudo da Tabela Periódica que mostra sempre ser um desafio. Há dificuldade em entender propriedades periódicas, aperiódicas, como os elementos foram dispostos na tabela e como essas propriedades se relacionam na formação das substâncias. Porém, muitos educadores tem apontado como solução para o problema o investimento em novas metodologias e aplicações práticas e vinculadas ao cotidiano dos alunos que facilitem o trabalho docente e a assimilação e produção dos conteúdos ministrados, por parte dos discentes, (MARANDINO, 2003).

Neste sentido, verifica-se a necessidade da utilização de formas alternativas relacionadas ao ensino de Química, como também a história da tabela periódica moderna, que despertem o interesse e a importância dos conceitos químicos presentes nos currículos escolares. É observável que as dificuldades no processo de ensino-aprendizagem de Química, infelizmente, são grandes muitas vezes porque os professores encontramse ligados a uma metodologia tradicional e os alunos costumam ter aversão aos conteúdos desta disciplina, por considerá-los de difícil compreensão, o que torna deficiente o processo de ensino-aprendizagem (FLEURY, 2005).

Tendo em vista a complexidade da compreensão dos conteúdos de Química desenvolveu-se esta pesquisa com o intuindo de identificar qual a concepção do alunado a respeito da tabela periódica e de averiguar o grau de conhecimento dos mesmos sobre a correta utilização da tabela.

\section{METODOLOGIA}

Inicialmente, relizou-se um levantamento bibliográfico sobre o tema a ser pesquisado. Posteriormente a pesquisa foi realizada com discentes matriculados no $1^{\circ}$ ano do Ensino Médio da Escola Técnica de Saúde, do CFP/ UFCG, Campus Cajazeiras, onde foram entrevistados 30 alunos da referida instituição. A coleta de dados foi realizada através de um questionário, no sentido de caracterizar o grau de afinidade com a disciplina de Química, a importância de estudar a história da evolução da tabela periódica e identificar se o alunado apresentava conhecimento a respeito do uso correto da tabela periódica e como os elementos encontram-se distribuídos na mesma. Por último, os dados foram analisados e tratados para posterior quantificação em forma de gráficos.

\section{RESULTADOS E DISCUSSÃO}

A partir dos dados obtidos foi possível caracterizar o real conhecimento dos discentes do Ensino Médio da Escola Técnica de Saúde, do CFP/ UFCG, de Cajazeiras, a respeito da Tabela Periódica Moderna.

Inicialmente procuramos identificar o grau de afinidade dos alunos com a disciplina de Química. Como mostra a Gráfico 1, onde cerca de $60 \%$ dos entrevistados indicam gostar de estudar química, justificando ser uma matéria relacionada ao cotidiano. Já outros 37,7\% destes responderam não gostar da disciplina, por ser complexa e exigir muito raciocínio. E ainda 2,3\% não quiseram responder. 


\section{Afinidade Pela Disciplina de Química}

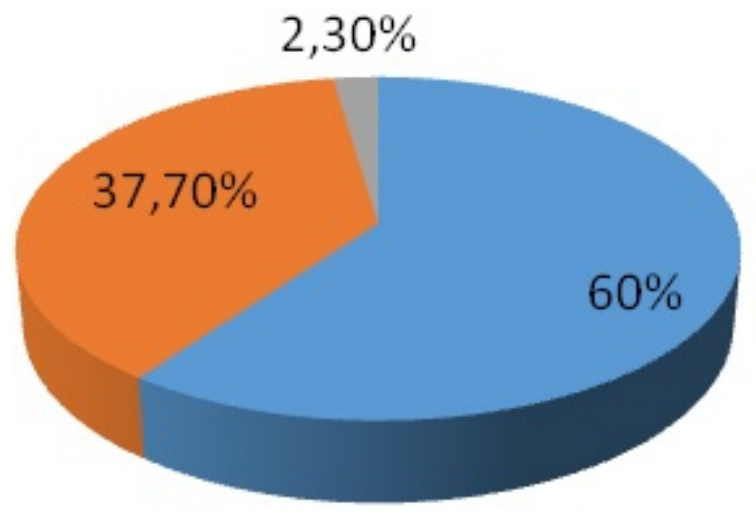

- Gostam de Química

Não Gostam de Química

- Não Quiseram

Responder

Gráfico 1 - Grau de Afinidade dos Alunos com a Disciplina de Química

Como mostra a Gráfico 2, quando questionados sobre a importância de se estudar a História da Evolução da Tabela Periódica, observou-se que 45\% dos alunos responderam ser importante, pois ajuda na compreensão dos conteúdos químicos. Já 33\% dos entrevistados disseram que ajuda a entender como os elementos químicos foram descobertos. Ainda 15\% afirmaram não ter nenhuma importância. E 7\% destes não quiseram ou não souberam responder.

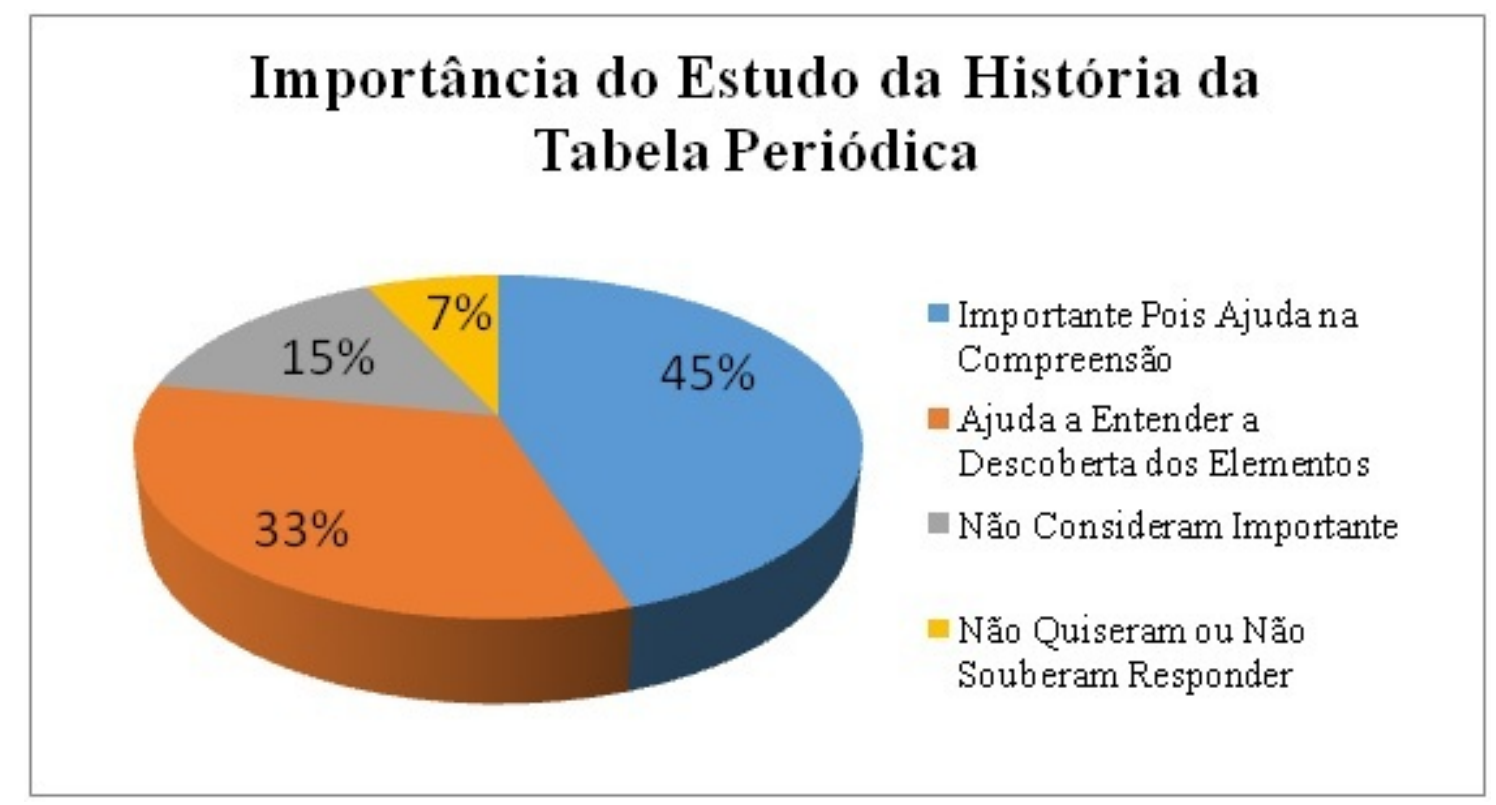

Gráfico 2 - A Importância de se Estudar o Histórico da Evolução da Tabela Periódica

Quando interrogados sobre o conhecimento a respeito do uso correto da tabela periódica e como os elementos encontram-se distribuídos na mesma, conforme podemos observar no Gráfico 3, A grande maioria, 77\% dos alunos reconheceram que não sabem utilizar a tabela de forma correta, isso deve-se a grande complexidade do assunto. Os discentes confirmaram que ainda não conseguem diferenciar grupo de período, e tem dificuldade na localização dos elementos. Em contrapartida, cerca de 33\% destes, afirmaram saber utilizar a tabela e que é organizada em grupos e períodos. 


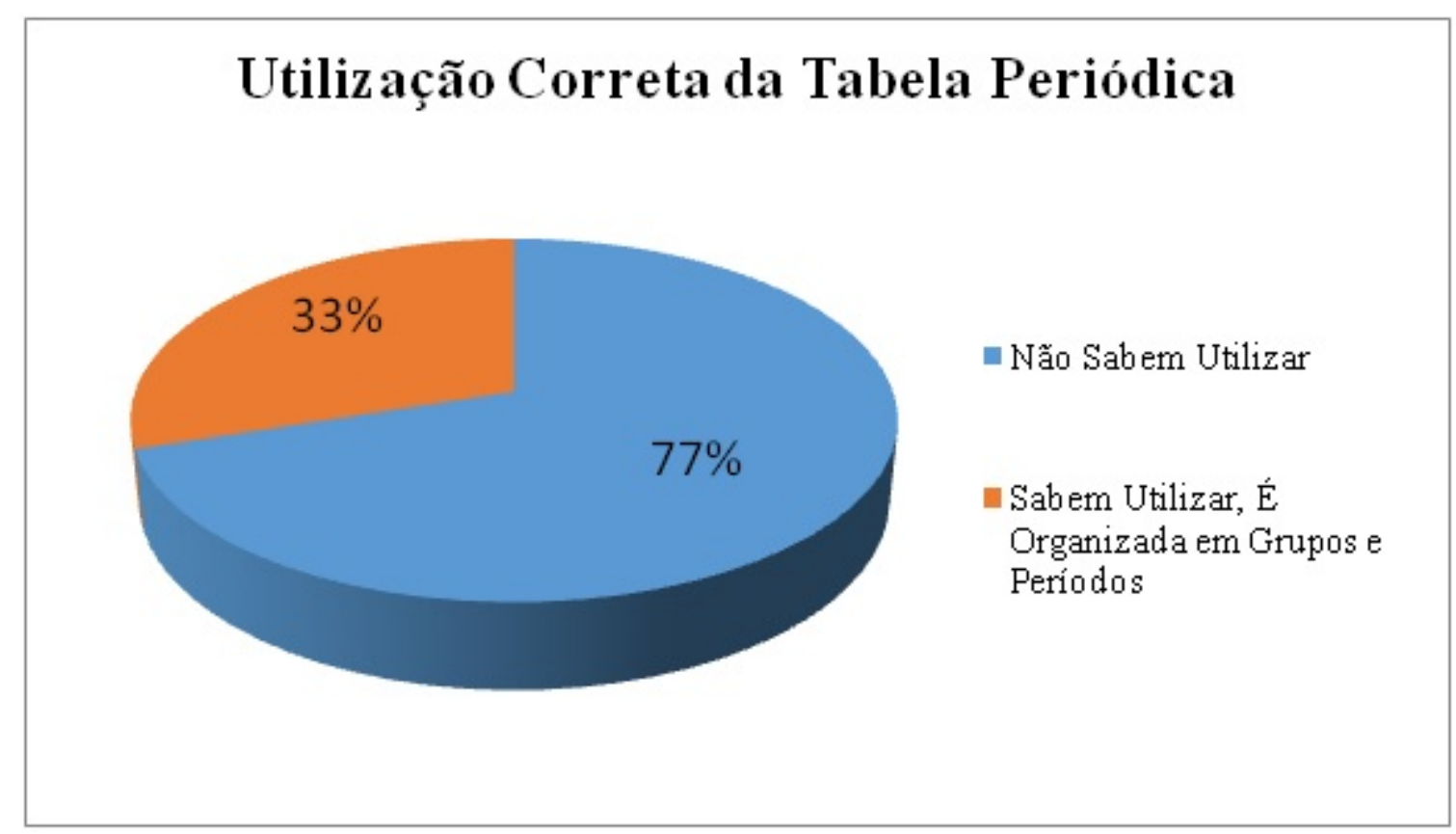

Gráfico 3 - Identificação do Conhecimento Prévio a Respeito do Uso Correto da Tabela Periódica

\section{Conclusões}

Os resultados evidenciam que há dificuldade por parte dos alunos na absorção dos conteúdos de Química, mais precisamente na utilização da Tabela Periódica. Observou-se que 77\% dos entrevistados afirmaram não saber usar a tabela de maneira correta, porém quando questionados a respeito da importância de estudar a Historia da Evolução da Tabela Periódica, observou-se que 45\% dos alunos responderam ser importante, pois ajuda na compreensão dos conteúdos químicos. Deste modo ficou evidente a necessidade de se desenvolver novas metodologias de ensino, buscando diminuir e/ou excluir essa deficiência do alunado com a disciplina de Química relacionada ao uso da Tabela Periódica.

\section{Law of Conservation of Mass : Experimentation and Context}

Albstract:Experimentation in Chemistry teaching classes is occupying more and more an essential space in the process of teaching and learning. As a way to research this teaching methodology, this paper presents results of a survey conducted in conjunction with the execution of an experimental activity, developed with students of the 2nd year of high school at the State School of Elementary and High School ProfessorManoelMangueira Lima, located in the city of Cajazeiras-PB. Aiming to contextualize the study of the Law of Conservation of Mass, began the activities with enhanced theoretical knowledge by reading periodicals related to the subject. Then the students ministered practical classes using low-cost alternative materials focusing on the theme proposed in the study. Before and after the classes, applied with the students of that school A semi-structured interview for consideration and weighting of the students of knowledge. The survey results were presented through graphs. We can show through this work, that the alliance of lectures in context with practical classes only comes to contribute a significant learning by allowing the construction of 
knowledge. Thus, the use of experimentation in the classroom ends up taking the students to get involved in the construction of scientific knowledge, making them able to relate chemistry to everyday life, showing them that chemistry is present in the daily lives of each. And to be able to contextualize the Chemistry teaching, it is necessary to take into account prior knowledge of the students, so as to introduce the satisfaction of the scientific theoretical knowledge.

Keywords: Law of Conservation of Mass; Experimentation; Contextualization.

\section{Referências bibliográficas}

MARANDI NO, M. A Prática de Ensino nas Licenciaturas e a Pesquisa em Ensino de Ciências: questões atuais. Cad. Bras. de Ensino de Física, V. 20, №. 2.: Agosto de 2003.

FLEURY, E.M; MACHADO, A.H. Química.Scipione.São Paulo: 2005.

GODOI, Thiago Andre de Faria; OLIVEIRA, Hueder Paulo Moisés de; CODOG, Lúcia Tabela Periódica - Um Super Trunfo para Alunos do Ensino Fundamental e Médio. Química Novana Escola, Vol. 32, № 1.: Fevereiro 2010.

PAULA, Giselle de Souza; CASSIANI,Suzani.O papel do professor da escola na formação do futuro docente de ciências: um discurso no silêncio.EntreVer, V. 01, №.01.: 2011. 